\title{
HUMAN RIGHTS IN TIMES OF THE PANDEMIC: A DIALOGUE ON MIGRATION AND INDIGENOUS RIGHTS IN BRAZIL BEFORE THE REGIONAL INTER-AMERICAN SYSTEM
}

\author{
LETÍCIA VIRGINIA LEIDENS ${ }^{1}$; PATRICIA NOSCHANG GRAZZIOTIN ${ }^{2}$
}

\begin{abstract}
This paper using the deductive method of approach based on regional scope for the protection of human rights, aims to demonstrate that the Brazilian state actions took during the pandemic, in terms of strategies, policies and measures to deal with the COVID-19 pandemic had severe consequences specially for indigenous and migrants population in Brazil, increasing the level of vulnerability of that population in its territory. It will also consider that in spite of adhering the unconditional observance of inter-American and international standards on human rights, the Brazilian government ignored such agreements and therefore causing social economic losses and about hundreds of deaths.
\end{abstract}

Keywords: COVID-19 pandemic; IAHR Commission with Resolution No. 01/2020; indigenous population; human rights; migrants population; vulnerable peoples.

Summary: 1. Introduction. 2 Human Rights in Pandemic Times: The Movement of International Organizations. 3 Evidence of Omissions by the Brazilian Government in Violating the Rights of Indigenous Peoples and Migrants. 4 Closing Remarks.

\section{$1 \quad$ INTRODUCTION}

This paper seeks to encourage reflection on human rights in times of the coronavirus pandemic - COVID-19, based on the theoretical exploration of the recurring commonplace of the human rights "crisis". As a parameter, we will highlight the movement of the Inter-American Human Rights System (IAHRS) with the publication of Resolution No. 01/2020 by the Inter-American Commission on Human Rights, highlighting the concern with the pandemic scenario and human rights in the Americas, with special emphasis on the Brazilian case, considering the migrants and indigenous people. This is mainly a documentary research, using the deductive method in the analysis of Resolution No. 01/2020 of the Inter-American Commission on Human Rights, published amidst the pandemic scenario, in addition to doctrinal texts of a legal nature. The theoreticaldogmatic methodology is therefore adopted, based on contemporary human rights debates.

\footnotetext{
${ }^{1}$ Adjunct Professor of Private International Law and Human Rights at Federal Fluminense University, Brazil (lleidens@gmail.com).

${ }^{2}$ Adjunct Professor of International Law at the Law Faculty of the University of Passo Fundo - UPF, Brazil (patriciagn@upf.br).
} 


\section{HUMAN RIGHTS IN PANDEMIC TIMES: THE MOVEMENT OF INTERNATIONAL ORGANIZATIONS}

The coronavirus pandemic - COVID-19 scenario frames the violation of human rights in Brazil and Latin America as more complex and severe, denouncing the cruel sides of capitalism and our regional distance to the culture of human rights. The debate takes urgency and necessity, as presuppositions of State actions, and puts us again as a social body, in a position of vigilance to the person's legality and dignity, above all, watchful to the emergence of a state of legal exception (Paes, et al., 2020, p. 561). The concern is how the State will act exceptionally, in particular with the treatment of human rights, when it already showed a tendency towards the movement of weakening and denial of rights, passing, to a certain extent, by the fragility of institutions and the legal and social structures conquered for everyone.

The analysis goes through the clarity that social inequalities of all orders are supported by the capitalist system, characterized as neoliberalism, in the context of globalization, which is reproduced by consumption, based on the accumulation of capital by a specific group. In this context, there is a recognition of the great distance or even opposition between capitalism and human rights, given that the failure to achieve rights for all appears as a feeding mechanism for that structure. The capitalist logic needs social inequality to maintain itself, being its systemic, structural, and founding base (Leford, 2011, p. 187). Therefore, in the theoretical and thinking fields, the perspective must consider the depth and complexity of the theme, especially for reducing social asymmetries. This implies that it is no longer just an economic model, but a cultural proposal positioned itself as natural and normalizes social subjects' behaviors and actions, therefore, of a much broader, more complex, and profound structure for a process of alteration. With the coronavirus pandemic - COVID-19, such questions become more evident, mainly when we reflect: who are the people behind COVID-19 inequality? Who is profiting? Who are the primary victims of this context? In this respect, one must consider the socio-economic disadvantage and of fields of possibilities for the countries of the Global South, notably a Brazil demarcated by deep inequalities and incapacitated in safeguarding the protection of citizens' life, health, physical integrity, and security. (Leidens, 2021, p. 140). Issues related to gender, class, and race are aggravated by a scenario of corruption and impunity that permeates the reality of the Americas and imposes a state political movement and urgent sanitary measures (Gonçalves, 2020, p. 318).

On the other hand, in the strategic field of human rights, we use the voice and concern shown by the regional structure for the defense and promotion of human rights, the Inter-American Human Rights System (IAHRS), specifically the Inter-American Court and the Inter-American Commission. The Inter-American System reverberates and highlights the worsening of structural problems involving human rights with the pandemic in the Americas. We consider both agencies as instruments that work for the transformation, promotion, and defense of human rights' culture in the international and regional contexts, chiefly when called upon to investigate, analyze and judge human rights violations. In the pandemic context, the IAHRS assumes the role of demarcation and surveillance and sheds light on problems already known, emphasizing the international commitments and 
obligations assumed by the States. The inter-American system's use ratifies its attribution as an instrument of assertion and stimulus for alternating an exclusionary and unequal reality with strengthening and recognizing the normative, recommendatory, and mandatory acts assumed by the State in international cooperation.

The Inter-American Commission issued Resolution No. 1/2020, which highlights its distress over the pandemic situation and human rights in the Americas. Also, the Inter-American Court issued a Declaration (Covid and Human Rights) describing the main problems and challenges for the States, pointing up to the States' international obligations from the perspective of human rights. The IAHR Commission Resolution appears more developed than the IAHR Court Declaration, covering a total of eighty-five recommendations, with regard to minimum standards of attitudes, state priorities, and the exaction of rights. Both documents signaled the concern with the defense of human rights and democracy in the pandemic scenario from a more open and not only sanitary approach, which is imposed by measures of access to health and infection prevention, protecting the right to health, life, and physical integrity.

On this subject, the main points highlighted by the IAHR Commission with Resolution No. 01/2020 are delineated: first, we highlight there is a notable concern with the use of state powers, in an exceptional circumstance, in the context of the coronavirus pandemic - COVID-19, that leads it to take measures, such as legislating, promoting public policies, restricting, redefining rights and priorities in the name of the exception or of the state of emergency. This restores the public movement, and when it does not agree with the human rights position, we can steer to a more elongated and deficient situation. The demarcation directs that public actions occur immediately and urgently, per the International Health Regulations (IHR) and with recommendations from WHO and PAHO to protect the fundamental rights and guarantees of citizens. This happens from the sharing, by the local and global spheres, of information and protocols seriously analyzed to outline alternatives on how to respond in an exceptional context. Consequently, the limits of state actions have been necessarily limited to institutional adaptations and modifications based on the sieve of proportionality, unique temporality, and exclusively to meet and fulfill the objectives that promote public health measures. Therefore, any public movements to restrict, redefine, or prioritizing rights and guarantees are only justified by the strict fulfillment of public health objectives ${ }^{3}$.

In a second aspect, the Resolution mentioned above emphasizes the concern in alerting States to give priority to the group of vulnerable people, especially women, blacks, indigenous peoples, children, migrants, and the LGBTIQ+ community, economically disadvantaged and who appear, historically, with stigmas and as focuses of oppression, violence, and discrimination, being the most affected by the COVID-19 pandemic, given the vulnerability that characterizes them (Benatti; Raiol; Lima, 2021, p.11). It is a scenario that aggravates the situation of the vulnerable, daily crossed by social, economic, and cultural inequalities, a structure that must necessarily be guided by the intersectionality bias between race, gender, and class. In this sense, the social gap reflects intensely, imposing

\footnotetext{
${ }^{3}$ In accordance with the following general principles and obligations (3).
} 
urgent, coordinated and prioritized state action by public policies aimed at the vulnerable: (...) "the formulation of public policies cannot distinguish different interests from those indicated by law, given the principles of public interest, purpose and impersonality" (Crenshaw, 1991, p. 1241) for the discriminated and marginalized social sectors.

The guidance of Resolution No. 01/2020 directs the priorities of the public movement, in an exceptional context, to address vulnerabilities in an inclusive, nondiscriminatory work of protection and tutelage, considering that only with this focus is it possible to contain the social impact that is announced.

Moreover, the IAHR Commission points to the path of multilateralism as a framework for strengthening human rights and respect for the rule of law and international cooperation, as structures that historically downplay the arbitrary use of state power. By this prospect, exceptional measures of human rights restrictions must necessarily materialize by law, in a reasonable manner, being strictly necessary, time-limited, and under scientific standards of exceptionality, in the name of public health. In addition to the international human rights conventions, such directives guide and limit state action, removing any attempts to consider the state of emergency a presupposition for a "blank check" in the suspension/underplaying of fundamental rights and guarantees (Ruiz; Neto, 2020, p. 162).

On the other hand, to verify how the Brazilian response to international stimuli occurs, above all, based upon the responsibility with international obligations assumed in a cooperative plan, is an urgent and decisive measure in this context. Immediately we are faced with the recurrent issue of internalization and prompt implementation of international (normative, recommendatory, and decision-making) acts in the Brazilian system, chiefly the integration of the international system with the internal system, which still is seen as an embarrassment between us (Piovesan, 2017, p. 135). This reflection, once linked to the decisions of the IAHR Court issued to Brazil, makes clear the recurrence of not fully complying with the obligations imposed by the IAHR Court's jurisdiction $^{4}$ (Coelho, 2008, p. 155) as well as with other guidelines of international organizations from the UN international agencies, under the grounds of the exercise of governmental sovereignty. It must be recognized that sovereignty has long acquired a non-absolute condition in international relations (Morgenthau, 1957, p. 123-5). It is noted that the current Brazilian behavior, in contrast with other countries and multilateralism, involves a width of analyses from the interdisciplinary field of historical, sociological, political, and international relations factors, essential to draw in-depth reflections on the positions adopted. In this sense, only with the use of an interdisciplinary approach and the analytical look's improvement it is possible to delimit justifications for the institutional and governmental components of the pandemic action.

\footnotetext{
${ }^{4}$ In Brazil, the implementation of decisions from the Inter-American Court of Human Rights is mandatory, in the same way as the national Judiciary branch of power's decisions. This obligation emerges not only from the ratification of the American Convention but also from the country's recognition of the contentious jurisdiction of the Court in the country.
} 
There are two aspects to this issue. We note that the denial or partial compliance with the decisions and guidelines of the IASHR and global for human rights compromises its strengthening as a system and as an instrument, since there is a space for questions about the role of multilateralism and international jurisdiction ${ }^{5}$. Conversely, it is up to the State to promote a positive and contributing movement out of its internal and institutional framework for the defense of the Democratic State of Law and the commitment to human rights in meeting regional and global positions, also including civil society's active space in demanding a coherent positioning of state institutions with the normativeness, for an inclusive, non-discriminatory and non-violent culture of human rights (Ruiz; Neto, 2020 , p. 160). Therefore, considering that such arguments were already rampaging as legal and political difficulties in the Brazilian scenario before the coronavirus pandemic COVID-19, it is necessary to reverberate this discussion so that the institutional responses follow the urgency required at the moment.

\section{EVIDENCE OF OMISSIONS BY THE BRAZILIAN GOVERNMENT IN VIOLATING THE RIGHTS OF INDIGENOUS PEOPLES AND MIGRANTS}

The pandemic further highlighted the vulnerabilities of certain groups in Brazil and deepened human rights violations, especially regarding indigenous peoples and migrants. Given this perspective, we seek to demonstrate how these violations have been enabled by normative acts that run counter to treaties protecting human rights and the national policy for the protection of human rights that has been developed since the enactment of Brazil's 1988 Constitution, when the re-democratization of the Brazilian state was fulfilled. It is also important to signal that the current Brazilian government has been ignoring the recommendations of the Organization of American States on preventing and fighting the Covid-19 pandemic.

Before the beginning of the pandemic, the government of President Jair M. Bolsonaro had already been forwarding acts against the protection of human rights. To exemplify, one of such measures was Decree No. 10.087/2019, which extinguished the Monitoring Committee of the National Program of Human Rights-3. Opposing this, the National Human Rights Council issued Recommendation No. 27 in December $2019^{6}$, prescribing that the National Human Rights Program - PNDH-3 be respected and enforced immediately. Among

\footnotetext{
${ }^{5}$ We reiterate that the inexistence of an organ/committee/commission within the system for such enforcement leaves this attribution to the State's responsibility. This calls for a state contribution to consolidate international jurisdiction since the system chooses not to engage in practices that interfere with States' autonomy and sovereignty. This means the absence of this body does not compromise arbitrariness in the fulfillment of decisions.

${ }^{6}$ The National Human Rights Program is part of a process of building commitment, by the Brazilian State, to human rights which starts in 1996 with the promulgation of the first National Human Rights Program and is reinforced by the second National Human Rights Program in 2002, being a state policy rather than a government's one. In its third document, PNDH-3, it summarizes the $11^{\text {th }}$ National Conference of Human Rights, preceded by regional state and municipality conferences: an example of good practices for implementing what was provided for the 1988 Federal Constitution and the Vienna Convention of 1993: universality, indivisibility and the interdependence of human rights. Recomendation $\mathrm{n}^{\mathrm{o}} 27$, on dec. 11 th of 2019. (Conselho Nacional de Direitos Humanos, 2019)
} 
the council's requests is the re-creation of the Committee with the repeal of Decree No. $10.087 / 2019$ in regards to its extinction - which evidenced multiple government's efforts contrary to international documents and commitments that Brazil upholds. ${ }^{7}$

The Brazilian government has adhered to unconditional inter-American observation and international standards on human rights. Therefore, taking into account the universal aspect of human rights: interdependent, indivisible, and interrelated, particularly for economic, social, cultural, and environmental rights, and applied primarily to indigenous and migrant populations in Brazil. The pandemic increased the level of vulnerability of those groups in the country.

Since the beginning of the Covid-19 pandemic, the Brazilian President has shown negligence and carelessness with the disease and the infected Brazilians who passed away. In one of the first public demonstrations by Bolsonaro, he considered Covid-19 a simple light flu. The disregard for the disease and his primary concern with the economy to the detriment of human lives have become visible with the replacements of the minister of Health, which is responsible for the oversight of public health at the national level. The head of the Ministry was changed three times, as the first two ministers to occupy the position supported stricter social distancing measures (horizontal) - which would logically damage the economy. Consequently, they did not remain in office. From May 15, 2020, to September 16, 2020, the country was left without an official minister in the office, as Army general Eduardo Pazuello assumed the ministry for this period on an interim basis, being officially nominated in mid-September. It is already half of 2021, and Brazil has its fourth Health minister amid the pandemic and reached the mark of 400 thousand deaths from Covid-19 last April (Ministério da Saúde, 2021).

The lack of management fighting the pandemic becomes even more evident for the vulnerable and low-income population. Deaths due to Covid-19 have been higher in environments where poverty, hunger, and malnutrition of the Brazilian population worsened.

\footnotetext{
${ }^{7}$ Pointing to the many actions and demonstrations of the federal government in 2019 that contradict programmatic actions, objectives and guidelines of the PNDH-3, such as: Programmatic Action A (Draft law to establish the National Prevention Mechanism, an inspection system for detention sites for the regular and periodic monitoring of deprivation of liberty centres, in accordance with the optional protocol to the UN Convention against torture and other cruel, inhuman or degrading treatment or punishment), Axis 4 (Public Security, Access to Justice and Combating Violence), Directive 14 (Combating institutional violence, with emphasis on the eradication of torture and the reduction of police and prison lethalities), Objective III (Consolidation of a national policy aimed at the eradication of torture and other cruel, inhuman or degrading treatment or punishment); Programmatic Action D (Progress in the implementation of agrarian reform as a means of social inclusion and access to basic rights, in articulation with health, educational, environmental and food production policies), Axis 2 (Development and Human Rights), Guideline 4 (Implementation of sustainable development models with social and economic inclusion, environmentally balanced and technologically responsible, culturally and regionally diverse, participatory and non-discriminatory), Objective I - Implementation of public development policies with social inclusion; Programmatic Action D ensures the demarcation, homologation, regularization and disintrusion of indigenous lands, in harmony with the projects of the future for each indigenous people and ensuring their ethnodevelopment and their productive autonomy, with Axis 3 (Universalizing Rights in a Context of Inequalities), Directive 7 (Guaranteeing Human Rights in a universal, indivisible and interdependent way, ensuring full citizenship) (...)
} 
Regarding indigenous peoples' rights, the Resolution No. 1/2020 determines the separation and voluntary isolation of indigenous populations must be appreciated, considering that the impact of infectious diseases to indigenous peoples' health, due to a situation of vulnerability, will always be heavier. Also, the Resolution states all measures should be taken to protect indigenous populations' human rights within the context of the pandemic, with preventive actions to guarantee their health. It is important to mention that the indigenous people are not vulnerable but in this time they are mainly vulnerable especially regarding the current and historically attacks and the way of they had been treat by the Brazilian government (Mondardo, 2020, p.83).

The federal government's disregard for the disease and its spread to the lowincome population had a devastating effect on the indigenous peoples, leading President Bolsonaro to be denounced at the International Criminal Court for committing genocide against the Brazilian indigenous population. In a repetition of the path established by the country's colonizers, the isolated indigenous population in the forests still suffers from the invasion of gold miners and deforestation. These are some of the practices that increased during the pandemic due to the lack of federal supervision. As it mention by Eduardo Vieiros de Castro "The disease is also spreading in the forest. With the confinement, the NGOs that protected these territories were put on hold. Entire regions are being invaded by gold miners, by illegal logging and by evangelical missionaries, to whom Bolsonaro has given carte blanche to infiltrate indigenous lands"(Viveiros de Castro, 2020a, p. ).

In December 2020, prosecutor Fatou Bensouda's office announced that it would begin a preliminary analysis of the complaints filed by the Arns Commission and the Human Rights Advocacy Collective regarding the evidence of crimes against humanity and the genocide of indigenous people (Comissão Arns, 2020). In January 2021, the tribal chiefs Raoni Metuktire and Almir Suruí have filed a new complaint against Jair Bolsonaro, demonstrating the violence and murder of indigenous leaders, as well as the deforestation increase in Brazilian biomes and the "criminal management of the pandemic by the Brazilian government for the indigenous populations"(Comissão Arns, 2020); (Boudons, 2021, p.1-69).

The complaints to the ICC were added to the request for precautionary measures filed on July 16, 2020, by the Munduruku Wakoborũn Women's Association and others, in favor of the members of the Munduruku Indigenous People to the Inter-American Commission on Human Rights ${ }^{8}$, requesting that Brazil take the necessary procedures to protect the right to life and personal integrity, given the failures in healthcare and the continuous presence of unauthorized third parties in indigenous peoples' territories. However, the government's request for precautionary action was not enough to stop the influx of miners into the lands of the Munduruku people. Since March 2021, the activity of illegal miners has intensified in the region, mainly with attacks against the Munduruku People's Association of Women, which has a historical struggle against unlawful mining invasions. These attacks led the federal prosecutor's office at the state of Pará to send a

\footnotetext{
${ }^{8}$ Resolution 94/2020. Precautionary Measures. No 679-20. Membros do Povo Indígena Munduruku em relação ao Brasil [2021
} 
notification to the Brazilian Attorney General requesting the Supreme Court (STF) to "declare the violation of human rights and request federal intervention in the state for the strict purpose of guaranteeing the provision of public security in the Jacareacanga region and contain the escalation of attacks by garrisons against indigenous leaders, associations and, ultimately, the Munduruku people themselves." (Ministério Público Federal, 2021)

The fight for land demarcation and recognition of indigenous peoples' rights in Brazil is not only contemporar. (Viveiros de Castro, 2020b, p.138-140 ). Violations of rights and invasions in indigenous lands by illegal operators extracting lumber from the Amazon Rainforest intensified lately - or rather have been tacitly endorsed by the current federal government. The report made by the National Research Institute (INEP, 2020) linked to the Project for Brazilian Legal Amazon ${ }^{9}$ refers to the complaint filed by "Caciques" Raoni and Suruí, pointing out that the estimated scope of deforestation ${ }^{10}$ from August 2018 to July 2019 is $10.129 \mathrm{~km}^{2}$ (2.5 million acres) of shallow cut. The states of Roraima (202.56\% increase), Acre (53.60\%), and Pará (52.04\%) have been affected the most by deforestation.

The Rights of Indigenous Peoples ${ }^{11}$, as well as the protection of the environment, ${ }^{12}$ appear in 1988's Brazilian Constitution, but the Judiciary ${ }^{13}$, since the enactment of the Magna carta, has been called upon to guarantee these rights. Regarding the demarcation of indigenous territories, according to the National Indigenous Foundation (FUNAI), "currently there are 488 regularized indigenous lands that comprise about $12.2 \%$ of the national territory, located in all biomes and more prominently in the Legal Amazon." This concentration results from the process of recognition of these lands, initiated by FUNAI, mainly during the 1980s within the framework of the policy of national integration and consolidation of the economic frontier in the Northern and Northwestern regions of the country (Fundação Nacional do Índio, 2021).

However, there are claims still demanding the demarcation of indigenous territories and the recognition of their ancestral lands. Some of them were brought to the InterAmerican System for the protection of human rights to be analyzed by the Inter-American

\footnotetext{
${ }^{9}$ The Legal Amazon refers to the nine Brazilian states with territorial presence within the rainforest: Acre, Amazonas, Amapá, Maranhão, Mato Grosso, Pará, Rondônia, Roraima and Tocantins.

${ }^{10}$ This is based on data generated by the Deforestation Monitoring Project in the Legal Amazon by Satellite (PRODES). It uses Landsat satellite images or similar to record and quantify deforested areas larger than 6.25 hectares (15.44 acres). PRODES considers deforestation the complete removal of the primary forest cover by shallow cutting, regardless of the future use of these areas. The estimate was quantified from the analysis of 229 images of the Brazilian Legal Amazon. ibid.

${ }^{11}$ Article 231. Brasil. Constituição Federal, 1988.

${ }^{12}$ Article 225. Brasil. Constituição Federal, 1988.

${ }^{13}$ The Brazilian judiciary received, between 1986 and 2020, 88,566 cases concerning environmental issues in the Amazon. Of these, 24 thousand cases of environmental damage, 16 thousand crimes against the flora and 11 thousand repeals or cancellations of fines. In addition, there were more than 11 thousand public civil actions, more than 8 thousand environmental crimes and 1,115 sentencing executions. The study points out that the largest number of cases was received by the Federal Regional Court of the $1^{\text {st }}$ Region (TRF-1), which registered 34,915 environmental disputes related to the region. [National Council of Justice] Justice and socio-environmental protection in the Brasilian Amazonia. (Conselho Nacional de Justiça, 2020.).
} 
Commission on Human Rights, and the case of the Indigenous People of Xucuru vs. Brazil was presented at the Inter-American Court of Human Rights.

In the meantime the Federal Supreme Court (STF) took an important mesure to safeguard the rights of indigenous peoples when suspended in nationwide all judicial proceedings and appeals relating to the demarcation of indigenous areas until the end of the COVID-19 pandemic. "The judgment noted that indigenous peoples had suffered for centuries from diseases that have often ended up decimating entire ethnic groups in the interior of the country because their immune systems were not equipped to deal with them" ${ }^{14}$ (STF, 2021)

In February 2021, the Inter-American Commission published a report on this body's in loco visit to Brazil on 5 and 12 November 2018 ${ }^{15}$, following Article 106 of the Charter of the Organization of American States. The report devotes 28 paragraphs to the grave violations of human rights suffered by indigenous peoples, already highlighting in 2018 what has further deteriorated with the Covid-19 pandemic. The conclusion to the document gathers 12 recommendations for indigenous peoples.

Violations also occur with the migrant populations. Concerning migrant citizens, refugees, and asylum seekers the same document recommends avoiding practices of expulsion or collective deportation, carrying out economic recovery actions to mitigate the crisis generated by the pandemic, and implement measures to prevent and fight against xenophobia.

Acting in contrary to those recommendations, the first measure taken against migrant populations was the closure of the border on March $17,{ }^{16} 2020$, forbidding the entry of foreigners from Venezuela. On March $19^{17}$, every Brazilian land border with

\footnotetext{
${ }^{14}$ In that regard, the judgment held that the continuation of proceedings could aggravate the situation of indigenous peoples and that, in order to minimize the risk of infection with coronavirus, the constitutional principle of precaution should be observed and, therefore, that the Government should act to reduce socioenvironmental risks in order to protect life and health. Finally, the judgment concluded that the nationwide suspension covered, among other cases, possessory actions, the annulment of administrative demarcation processes and appeals linked to such actions, without prejudice to the territorial rights of indigenous peoples, until the end of the COVID-19 pandemic (STF, 2021)

${ }^{15}$.Paragraph 56. In spite of the advancements registered in the legislation, the CIDH sees how worrying is the situation of native communities in Brazil. To the registers of invasion threats to their territories, deep challenges add up, as for title regulation and protection of lands. In countless cases, native communities don't get the necessary protection of the State. The Commission dedicates great preoccupation to the process of revision of the country's indigenous and environmental policies, whose current federal government favours the illegal occupation of ancestral lands - when acts of violence have been encouraged against the leadership and the native communities, and when the environmental destruction of their territories was authorized. (Inter-American Commission on Human Rights, Situation of Human Rights in Brazil. 2021a,b) ${ }^{16}$ Portaria $\mathrm{n}^{\mathrm{0}}$ 120, de 17 de Março de 2020 - Dispõe sobre a restrição excepcional e temporária de entrada no País de estrangeiros oriundos da República Bolivariana da Venezuela, conforme recomendação da Agência Nacional de Vigilância Sanitária - Anvisa. (Brasil, 2020a)

${ }^{17}$ Portaria $\mathrm{n}^{\circ} 125$, de 19 de Março de 2020 - Dispõe sobre a restrição excepcional e temporária de entrada no País de estrangeiros oriundos dos países que relaciona, conforme recomendação da Agência Nacional de Vigilância Sanitária - Anvisa. (Brasil, 2020b)
} 
neighboring countries ${ }^{18}$ was closed, except the one with Uruguay that, according to the executive action, would come afterward. Until May 2021, the migration policy continues to be administered via joint decrees from ministries determining restrictions on the entry of migrants and curbing the admission of foreigners through land and aquatic/maritime borders. Such administrative acts (resolutions) already count up to a dozen, bringing legal insecurity and also entirely in contradiction with the provisions for migrants in articles 3 and 4 of the Migration Act (Law 13,445 of 2017) and provided for refugees in the Convention on the Status of Refugees of 1951, the Additional Protocol of 1967 and Law 9,474 of 1998 - which accepted the provisions of the previous treaties.

Since the beginning of the pandemic, migrants, whether volunteers or applicants for refugee status, have found it challenging to regularize their situation. The Federal Police has restricted service to them, coming to understand that, with closed borders, there are no migratory controls to be carried out. In addition, due to social distancing measures, Federal Police offices remained closed for visits for a few months, and several migrants had their residence permits or visas expired, forcing an even greater demand for document regularization when the agency's activities resumed.

Data from June 2020 indicates that 97,209 requests for refugee recognition of Venezuelan (R4V 2021) ${ }^{19}$ migrants have not yet been analyzed by the National Refugee Committee linked to the Ministry of Justice. It is important to note that, even with the land borders closed, the migration influx has not ceased. Migrants from Venezuela and Haiti kept entering Brazilian territory undocumented, and the Federal Police refuses to receive requests for regularization on the grounds that migration is not authorized with the borders closed and deportation measures may be applied.

The Federal Police's argument violates both human rights treaties and the principle of non-return provided for the 1951 Geneva Convention. With expired documents, many migrants became even more vulnerable in Brazil, as without documentation, they cannot search for decent jobs. These actions reaffirm the vulnerability of migration as detailed by Said, as well as the understanding that migrants have a provisional status (Sayad, 1998, p.54).

Acts by the Brazilian government against the migrant population have been by it if common tornado in the North of Brazil. Two episodes exemplify it: the first one was the Brazilian government's act against the Migration Law and the protection of human rights when the use of force was authorized against Haitian migrants on the border between the state of Acre and Peru. They intended to leave Brazil for Costa Rica, Mexico, and the United States. The state of Acre, located in the north of Brazil bordering Peru and Bolivia, declared a state of emergency because of river floodings, dengue fever outbreaks, and the lack of hospital beds for Covid-19 intensive care. Therefore, it has faced an even more significant challenge than to provide shelter, healthcare, and security to migrants (Delfim, 2021).

\footnotetext{
${ }^{18}$ Bolivia, Colombia, French Guyana, Guyana; Paraguay; Peru; e Suriname.

${ }^{19}$ Plataforma de Coordinaciòn para Refugiados y Migrantes de Venezuela.
} 
The second one occurred at the invasion of a Venezuelan shelter in the city of Pacaraima, in the state of Roraima. Casa São José (Saint Joseph's House) lodges Venezuelan children and women and was raided by the Federal Police and by state civil and military police departments under the justification of compliance with a city decree stating the shelter was agglomerating people. At the time, 31 women and 40 children and teenagers had been accommodated in Casa São José, and without any court order, the police forces violated all human rights instruments mainly because of their vulnerability to migration and for being women and children (Araújo, 2021). The measure requested by the Federal Police was of collective deportation and infringed both the principle of non-return provided for the Geneva Convention and Brazilian Migration Law prohibiting collective deportation.

The United Nations Development Programme report from Latin America and the Caribbean also demonstrates that the Covid-19 is a crisis beyond healthcare: it is as well an opportunity to change governance. According to the report, the health crisis has to be understood as a crisis of governance. The document outlines three opportunities for change: in the arena of public policies; in the rules of the game; and in the actors involved in the political scenario (UNDP, 2021, p.6). The pandemic has intensified and demonstrated states' institutional vulnerabilities, and it has further evidenced social inequalities. It is necessary to work for a more effective healthcare system and a more resilient and equitable economy that generates equal access opportunities for the next decade.

\section{Closing Remarks}

We sought to instigate a reflection on human rights in a specific and expansive context, the coronavirus pandemic - COVID-19, based on the concern about the state tutelage movement and priority decision-making for access to rights in the face of the constant reality of the violation of human rights. The coronavirus pandemic - COVID-19 has imposed new tensions, confrontations, and attitudes in the individual, social and institutional fields, and, from them, new social formats that demonstrate the absence of the state and citizens' rights. In these aspects, the IAHRS in issuing international acts, in this case Resolution No. 01/2020 of the Inter-American Commission, by drawing attention to the concern with the pandemic scenario and human rights in the Americas, given the exceptional nature of the moment and its influence on decision-making, reverberates practices and measures from the perspective of human rights in a context in which the exception of the period cannot overturn the minimum conquests of citizens. The approach has shown topics of difficulty and sought to foster reflection based on questioning how we should think about these issues now, in a scenario of continuous transformation and difficult social reach for the culture of human rights and especially in the proposed analysis regarding to the migrant and indigenous population in Brazil. 


\section{REFERENCES}

ARAÚJO, F. (2021) Cáritas e outras 130 instituições repudiam invasão policial em casa que abriga venezuelanos em RR' G1, available at: https://g1.globo.com/rr/roraima/ noticia/2021/03/20/caritas-e-outras-80-instituicoes-repudiam-invasao-policialem-casa-que-abriga-venezuelanos-em-rr.ghtml

BENATTI, J. H., RAIOL, R. W. G., \& LIMA, T. da S. (2021). Os grupos vulneráveis no Sistema Interamericano de Direitos Humanos: a proteção do território dos povo indígena e comunidades tradicionais. [The vulnerable groups in the inter-american human rights system: the protection of the territory of indigenous peoples and traditional communities]. Revista Da Faculdade De Direito Da UFG, 45(1). https://doi.org/10.5216/rfd.v45i1.60006

BOUDONS, W. (2021) Comunicação nos Termos do Artigo 15 do Estatuo de Roma. (APUBLICA), available at: https://apublica.org/wp-content/uploads/2021/01/vfinale-portugais-amazonie-projet-de-communication-cpi-v5-confidentiel-copie. pdf.

BRASIL (1988) Constituição Federal, available at: http://www.planalto.gov.br/ccivil_03/ constituicao/constituicao.htm.

BRASIL (2020a) Portaria $n^{\circ}$ 120, de 17 de Março de 2020 — Dispõe sobre a restrição excepcional e temporária de entrada no País de estrangeiros oriundos da República Bolivariana da Venezuela, conforme recomendação da Agência Nacional de Vigilância Sanitária - Anvisa.

BRASIL (2020b) Portaria $n^{\circ}$ 125, de 19 de Março de 2020 - Dispõe sobre a restrição excepcional e temporária de entrada no País de estrangeiros oriundos dos países que relaciona, conforme recomendação da Agência Nacional de Vigilância Sanitária Anvisa.

BRASIL (2021) Ministério da Saúde. Coronavírus Brasil. Brazil. Available at: https:// covid.saude.gov.br/. [Accessed 11 May 2021].

COELHO, R. (2008) Proteção internacional dos direitos humanos: a Corte Interamericana e a implementação de suas sentenças no Brasil.1st edn, Juruá.

COMISSÃO ARNS. (2020) TPI informa avaliação preliminar da jurisdição do caso contra Bolsonaro, available at: https://comissaoarns.org/blog/2020-12-15-tpi-informaavalia $\% \mathrm{C} 3 \% \mathrm{~A} 7 \% \mathrm{C} 3 \% \mathrm{~A} 30-$ preliminar-da-jurisdi $\% \mathrm{C} 3 \% \mathrm{~A} 7 \% \mathrm{C} 3 \% \mathrm{~A} 30$-do-casocontra-bolsonaro/

CONSELHO NACIONAL DE DIREITOS HUMANOS. (2019) Recommendation $n^{0} 27$, de 11 dezembro, available at: https://www.gov.br/mdh/pt-br/acesso-a-informacao /participacao-social/conselho-nacional-de-direitos-humanos-cndh/Recomendaon 27PNDH3.pdf 
CONSELHO NACIONAL DE JUSTIÇA. (2020) Justice and socio-environmental protection in the Brazilian Amazonia. https:/www.cnj.jus.br/wp-content/ uploads/2020/11/JUSTICE-AND-SOCIO-ENVIRONMENTAL-PROTECTIONIN-THE-BRASILIAN-AMAZONIA_V-6_2020-12-16.pdf

CRENSHAW, K. (1991). Mapping the Margins: Intersectionality, Identity Politics, and ViolenceAgainstWomen ofColor.43 SLRev, 1241.https://doi.org/10.2307/1229039

DELFIM, R. (2021) Imigrantes no Acre vivem limbo em meio à Covid-19 e clima tenso na fronteira, available at: https://migramundo.com/imigrantes-no-acre-vivemlimbo-em-meio-a-covid-19-e-clima-tenso-na-fronteira/

FUNDAÇÃO NACIONAL DO ÍNDIO. (2021) Terras indígenas: o que é? (Fundação Nacional do Índico), available at: https://www.gov.br/funai/pt-br/atuacao/terrasindigenas/demarcacao-de-terras-indigenas

GONÇALVES, E. (2020). A necessária transição planetária: (in) convenientes para a benfazeja mudança no Brasil e na comunidade internacional de países. Sequência: Estudos Jurídicos e Políticos. V.41, n. 85, p. 309 - 335, ISSN: 0101-9562 https:// periodicos.ufsc.br/index.php/sequencia/article/view/72371/44600. doi: https://doi. org/10.5007/2177-7055.2020v41n85p309

INEP. (2020) A taxa consolidada de desmatamento por corte raso para os nove estados da Amazônia Legal (AC, AM, AP, MA, MT, PA, RO, RR e TO) em 2019 é de 10.129 km2.' http://www.inpe.br/noticias/noticia.php?Cod_Noticia $=5465$

INTER-AMERICAN COMMISSION ON HUMAN RIGHTS. (2020) Resolution n. 1/20 - Pandemic and Human Rights in the Americas. Washington.

INTER-AMERICAN COMMISSION ON HUMAN RIGHTS. (2021a) Situation of Human Rights in Brazil. Inter-American Commission on Human Rights. February 12 2021. OEA/Ser.L/V/II. Doc.9/21.

INTER-AMERICAN COMMISSION ON HUMAN RIGHTS. (2021b) Resolution 94/2020. Precautionary Measures. No 679-20. Membros do Povo Indígena Munduruku em relação ao Brasil, available at: http://www.oas.org/pt/cidh/decisiones/pdf/9420MC679-20-BR.pdf

LEIDENS, Letícia Virginia. COVID-19ANDHUMANRIGHTS:AFEWFRAMEWORKS BETWEEN HISTORICITY AND THE RESOLUTION No. 01/2020 OF THE INTER-AMERICAN COMMISSION ON HUMAN RIGHTS. Revista Juridica, [S.1.], v. 3, n. 65, p. 134 - 153, out. 2021. ISSN 2316-753X. Disponível em: <http:// revista.unicuritiba.edu.br/index.php/RevJur/article/view/4965>. Acesso em: 04 out. 2021. doi:http://dx.doi.org/10.21902/revistajur.2316-753X.v3i65.4965.

LEFORT, C. (2011) A invenção democrática: os limites da dominação totalitária. 3rd edn, Autêntica. 
MINISTÉRIO PUBLICO FEDERAL. (2021) MPF quer intervenção federal no PA para deter conflito entre garimpeiros e indígenas em Jacareacanga e entorno (atualizada), available at: http://www.mpf.mp.br/pa/sala-de-imprensa/noticias-pa/mpf-querintervencao-federal-no-pa-para-deter-conflito-entre-garimpeiros-e-indigenas-emjacareacanga-e-entorno

MORGENTHAU, H. (1957) Politics Among Nations: The Struggle for Power and Peace, Fifth Edition, New York: Alfred A. Knopf.

MONDARDO, M. (2020) Povos indígenas e comunidades tradicionais em tempos de pandemia da Covid-19 no Brasil: Estratégias de luta e r-existência. Finisterra, $L V$ (115), pp. 81-88. https://doi.org/10.18055/Finis20364

PAES, J. et al. (2020) A crise ampliada pela Covid-19 e os fundamentos jurídicos do dever horizontal de solidariedade no contexto contemporâneo brasileiro. Revista Jurídica, [S.1.], v. 4, n. 61, p. 552 - 591. http://revista.unicuritiba.edu.br/index.php/ RevJur/article/view/4878. doi:http://dx.doi.org/10.21902/revistajur.2316-753X. v4i61.4878.

PIOVESAN, F. (2017) Latin American Human Rights Ius constitutionale comune and the Inter-American Human Rights System: Perspectives and Challenges. Revista Direito e Práxis, 1356. https://doi.org/10.12957/dep.2017.28029

Plataforma de Coordinaciòn para Refugiados y Migrantes de Venezuela. (R4V).(2021) https://r4v.info/en/situations/platform/location/7509

RUIZ, I.; NETO, R.(2020) Primeiras impressões sobre o Estado e o Direito Social da Saúde em cotejo com o Coronavirus (Covid-19) e os efeitos jurídicos daí decorrentes. Revista Juridica, [S.1.], v. 5, n. 62, p. 141 - 167. http://revista.unicuritiba.edu.br/index. php/RevJur/article/view/4888. doi:http://dx.doi.org/10.21902/revistajur.2316-753X. v5i62.4888.

SAYAD, Abdelmalek. (1998) A Imigração: paradoxos da alteridade. São Paulo: EdUSP.

SUPREMO TRIBUNAL FEDERAL (STF) (2021) -n. 1031. Definição do estatuto jurídicoconstitucional das relações de posse das áreas de tradicional ocupação indígena à luz das regras dispostas no artigo 231 do texto constitucional. http:// www.stf.jus.br/portal/jurisprudenciaRepercussao/verAndamentoProcesso .asp? incidente $=5109720 \&$ numeroProcesso $=1017365 \&$ classeProcesso $=$ RE\&numero Tema $=10$

United Nations Development Programme. (UNDP) (2021) Latin America and the Caribbean: Effective Governance, beyond Recovery, available at: https://www. latinamerica.undp.org/content/rblac/en/home/library/democratic_governance/ america-latina-y-el-caribe--gobernanza-efectiva--mas-alla-de-la-.html

VIVEIROS DE CASTRO, E. (2020a) Ce qui se passe au Brésil relève d'un génocide [What is happening in Brazil is a genocide]. Philosophie magazine. https://www. philomag.com/ lactu/temoignages/eduardo-viveiros-de-castroce-qui-se-passeau-bresil-releve-dun-genocide43226?fbclid=IwAR2SOLVRupgMioHOEuDbu CKfbwmacAuCK2kLCfmOJNAJiWYJjRQSqimkCmE 
VIVEIROS DE CASTRO, E. (2020b). Sobre la noción de etnocidio, con especial atención al caso brasileño. Estudios de Historia Moderna y Contemporánea de México, n. 60. pp. 111-144. https://moderna.historicas.unam.mx/index.php/ehm/article/ view/71408/69128. https://doi.org/10.22201/iih.24485004e.2020.60.71408

Received: July $2^{\text {nd }} 2021$

Accepted: October $5^{\text {th }} 2021$

(c) $(7)(-$ 